visualize a threat to liberty in the action of a uniformed health inspector answering a routine complaint. Yet in an era when politically controlled officials have grown powerful through an ever increasing series of minor infractions of civil liberties, it would seem prudent to invoke the full force of the constitutional guarantees at every opportunity. ${ }^{30}$

\title{
DIVIDEND CREDITS FOR NONCUMULATIVE PREFERRED STOCK
}

In addition to seniority in the distribution of corporate earnings, the cumulative preferred shareholder receives a credit for dividend arrearages accruing when earnings are not sufficient to authorize distributions. Yet in some circumstances it may be undesirable to place the potential burden of such arrearages upon the corporation. Upon reorganization or at the commencement of ventures in which initial years of losses or low profits are anticipated, noncumulative preferred may be a sounder issue. Such stock issues pose a fundamental problem: do the noncumulative preferred shareholders receive a dividend credit for those years when profits are legally adequate to permit some distribution but the directors omit any declaration?

The United States Supreme Court rejected such a dividend credit for noncumulative preferred stock in Wabash Railway Co. v. Barclay. ${ }^{3}$ Speaking through Justice Holmes it asserted:

When a man buys stock instead of bonds he takes a greater risk in the business. No one suggests that he has a right to dividends if there are no net earnings. But the investment presupposes that the business is to go on, and therefore even if there are net earnings, the holder of stock, preferred as well as common, is entitled to have a dividend declared only out of such part of them as can be applied to dividends consistently with a wise administration of a going concern. When ... the dividends in each fiscal year were declared to be noncumulative and no net income could be so applied within the fiscal year referred to in the certificate the right for that year was gone. If the right is extended further upon some conception of policy, it is enlarged beyond the meaning of the contract and the common and reasonable understanding of men.

These arguments, in the context of the apparently plain meaning of "noncumulative" as against "cumulative," have prevailed in all jurisdictions except New Jersey, ${ }^{3}$ The New Jersey position, first expressed in the Cast Iron Pipe cases, 4 is based upon the belief that in the absence of a dividend credit there is

${ }^{30}$ See DeVoto, Due Notice to the FBI, Harper's Magazine (Oct., 1949) at 65.

× 280 U.S. $x 97$ ( 1930 ).

2280 U.S. 197,203 (1930).

3 But writers have advocated various forms of the dividend credit. See Frey, The Distribution of Corporate Dividends, 89 U. of Pa. L. Rev. 735, 750 et seq. (1941); Berle, Noncumulative Preferred Stock, 23 Col. L. Rev. 358 (I923). Frey asserts that most of the writers have approved the dividend credit. $89 \mathrm{O}$. of Pa. L. Rev. 735, 753 (I94I).

1 Bassett v. United States Cast Iron Pipe and Foundry Co., 74 N.J. Eq. 668, 7o Atl. 929 (Ig08), aff'd 75 N.J. Eq. 539, 73 Atl. 514 (I909). (A bill to enjoin the corporation from paying 
danger that withheld earnings will be appropriated for the benefit of the common shareholders. Such appropriation occurs whether the withheld earnings are directly distributed to common in subsequent years or are retained in the business, earning income and providing interest-free leverage for common. ${ }^{5}$ of course it is also true that retention of preferred's earnings in some measure benefits the preferred shareholders themselves, since the increased corporate capital better insures preferred's receipt of its fixed return. Moreover, where the withheld sum includes substantial earnings distributable to common and the dividend credit prevents their distribution before the credit is repaid, the preferred shareholder will receive the benefits of the withholding while common bears the major burden. Finally, the market may already have discounted the risk that common will appropriate earnings withheld from noncumulative preferred stock, so that adoption of the dividend credit would only create windfall gains. In the ordinary situation, however, preferred dividends are probably withheld in years when the common dividend would be insubstantial. The advantageous position of common with respect to such withheld sums appeared so inequitable to the New Jersey court that it imposed some of the incidents of cumulation upon the general noncumulative share agreement when there were earnings.

The New Jersey dividend credit accrues when earnings are sufficient to allow dividends on noncumulative preferred stock but are not so distributed. For this purpose, however, the concept of "earnings" has been limited so as to exclude various unusual accretions to surplus. ${ }^{6}$ The credit is unimpaired so long as the

a dividend to preferred out of surplus, there being no earnings in the year of distribution. The dividends were paid out of a "reserve for added working capital" which had always been invested in securities. The court held that no actual working capital had been appropriated, but that a corporate by-law would have allowed that in any case.) Moran v. United States Cast Iron Pipe and Foundry Co., 95 N.J. Eq. 389, I23 Atl. 546 (I924), aff'd 96 N.J. Eq. 689, I 26 Atl. 329 (rg24). (A bill brought by a common shareholder to enjoin payment of dividends to preferred in excess of the fixed annual dividend rate. Injunction denied.) Day v. United States Cast Iron Pipe and Foundry Co., 95 N.J. Eq. 38g, I 23 Atl. 546 (x924), aff'd 96 N.J. Eq. 736 , 26 Atl. 302 (1924). (A bill brought by a preferred shareholder to enjoin payment of dividends to common while the credit was outstanding. Injunction granted.)

- The return on preferred stock is fixed, and the previous capital was sufficient to meet that return. It follows that the return from the additional investment will go to common. The liquidation value of common, of course, will increase by the amount of the withheld sum. But appropriation takes place even in the absence of liquidation or dividend disbursement of the principal sum withheld, since the present value of a sum is equal to the discounted value of the future increments of income it will yield.

6 This limitation is defined in Dohme v. Pacific Coast Co., 5 N.J. Super. 477,68 A. 2 d 490 (r949), and Agnew v. American Ice Co., 2 N.J. 29r, 66 A. 2d 330 (x949). The Dohme case held that gains from the corporation's acquisition of its own bonds at a discount were not available for noncumulative preferred dividends. The Agnew case was also concerned with the problems of determining whether various accretions to surplus were available for preferred dividends. Thus the New Jersey court has undertaken the very difficult task of classifying accretions to surplus. Under the Dohme case it appears that accretions to surplus not giving rise to a dividend credit can be distributed to common in a year where there are no distributions to 
earned surplus has remained high enough to cover it, ${ }^{7}$ and has not been "applied" to certain "legitimate corporate purposes." So long as a dividend credit exists, no dividends can be paid on common stock. 9 Any preferred dividends, not in satisfaction of a dividend credit, but in excess of current earnings are subtracted from the credit. ${ }^{10}$

These specialized characteristics of the New Jersey dividend credit underline the restriction it has undergone since the court first asserted in Day v. United States Cast Iron Pipe and Foundry Co. ${ }^{11}$, that the only distinction between cumulative and noncumulative stock lay in cumulative's credit for arrearages when there were no earnings. Thus in Lich v. United States Rubber Co. ${ }^{\text {I2 }}$ the federal district court asserted, by way of dictum, that the credit would be lost if the surplus were "applied to legitimate corporate purposes such as payment of debts, reduction of deficits, capital improvements or extensions, and other ordinary business requirements." "' The same language was employed in Dohme

preferred. 63 Harv. L. Rev. 89o, 89I (I950), noting Dohme v. Pacific Coast Co., supra. The New Jersey court was concerned with a problem on the order of the following. If excessive bad debts reserves had been charged in years when preferred was paid its dividends, income treatment of a writing down of this reserve in a year when there was no corporate income would result in appropriating what should have been common earnings in previous years to preferred in the current year. Thus the Dohme rule is an attempt at a common dividend credit. The other policy reason behind this attempt at classification is the reluctance to allow preferred the benefit of gains to surplus which are not connected with the ordinary operations of a given year (for example, bond retirement at a discount) and a corresponding disinclination to make preferred bear the greater burden in the event of extraordinary losses (expropriation, acts of God, etc.) in years where ordinary income is about equal to preferred dividends. Thus, these items are allowed to be directly transferred to surplus. Agnew v. American Ice Co., supra. For an example of the numerous problems arising in this area see Agnew v. American Ice Co., supra at 65 a. Problems existed with reference to depreciation allowances, redemption of securities, writing off of doubtful accounts, and deduction of "provision for contingencies" from net income. It should be noted that the New Jersey court has superimposed added difficulties to the already complex task of defining corporate income. There seems no reason to discriminate generally between common and preferred in eligibility for receipt of unusual increments to surplus.

7 Day v. United States Cast Iron Pipe and Foundry Co., 95 N.J. Eq. 389, I23 Atl. 546 (I924), aff'd 96 N.J. Eq. 736, x26 Atl. 302 (I924).

${ }^{8}$ Dohme v. Pacific Coast Company, 5 N.J. Super. 477, 68 A. 2d 490 (I949). Of course, technically the surplus is not "applied" to corporate ends. When debts are retired or machinery purchased, only the form of the assets is changed. Cash may be applied to corporate ends, but not surplus.

9 Day v. United States Cast Iron Pipe and Foundry Co., note 7 supra. But consider the implications of the Dohme rule discussed in note 6 . It appears that certain increments to surplus could be distributed to common even in the face of a dividend credit.

${ }^{30}$ Agnew v. American Ice Co., 2 N.J. 29r, 66 A. 2d 330 (I949).

${ }^{x} 96$ N.J. Eq. 736, 740, I26 A. 2d 302, 304 (x924).

I2 39 F. Supp. 675 (N.J., I94I).

${ }^{{ }^{3}} 39$ F. Supp. $675,68 x$ (N.J., I94I). The holding of the Lich case was that a dividend credit did not accrue in those years in which there were earnings without corporate distribution, but where a surplus net deficit existed. 
v. Pacific Coast Co. ${ }^{24}$ where it was held that repurchase of corporate bonds at a discount was not one of these ordinary business requirements..$^{15}$ Although the basic argument for the dividend credit persists even where earnings are "ploughed back" (since common receives the income earned by what amounts to a forced capital contribution), New Jersey is unwilling to allow the credit unless those earnings are held in the form of cash, investments in securities or other uses defined to be outside ordinary business requirements. But since stockholders may sometimes force dividend distributions by injunction where earnings can be shown to be withheld without purpose, the dividend credit may be superfluous in those very instances in which it accrues. Since directors can usually justify withholdings as necessary to meet possible contingencies, the dividend credit faces the danger of complete extinction if withholdings to meet legitimate contingencies are "legitimate corporate purposes" within the meaning of the dicta in the Lich and Dohme cases. While this danger is presently unrecognized by the New Jersey court, it will present a continual threat as the court struggles with the problem of drawing the line between ordinary and extraordinary business uses. In any event, the New Jersey rule has been so narrowed that the Wabash case would be decided identically by the Supreme Court and by the New Jersey court. ${ }^{26}$

The apparent disintegration of the New Jersey rule has been both subtle and inarticulate. In the Cast Iron Pipe cases the withheld dividends were clearly correlated with an unused reserve for added working capital. ${ }^{17}$ Consequently no substantial discussion of "employment for legitimate corporate purposes" appeared, and it was easy to engraft the Lich dictum onto these early cases. The Dolme situation was the first to test the Lich doctrine which had declared that retirement of bonds was an ordinary business activity. Although the court enthusiastically embraced the doctrine verbatim, it then decided that retirement of bonds was not ordinary business activity reducing the dividend credit. The Lich doctrine is apparently limited to this extent..$^{8}$ More important, however, the New Jersey court is seemingly unaware that its present distinction is almost completely irrelevant to the policy of the dividend credit rule. The unhappy marriage of the dividend credit with the "ordinary business requirement" criteria would have been prevented had the New Jersey court realized that the

${ }^{24} 5$ N.J. Super. 477,68 A. 2 d 490 (I949). Similar language appears in Agnew v. American Ice Co., 2 N.J. 29r, 303, 66 A. 2d 330, 336 (r949).

Is But note the contradiction this results in. See text at note 18 infra.

${ }^{16}$ Among the operative facts of the Wabash case is the employment of the withheld earnings as working capital.

${ }_{77}$ The same fact situation existed in Cintas v. American Car and Foundry Co., I3I N.J. Eq. 4I9, 25 A. 2d 4I8, aff'd I32 N.J. Eq. 460, 28 A. 2d 53 I (I942).

${ }^{28}$ Certainly repurchase of corporate bonds is equivalent to "retirement of debt." Compare 5 N.J. Super. 477,88 A. 2 d 490 (I949). 
form of the assets representing withheld earnings has no relation to the equitable rights of noncumulative shareholders at distribution. ${ }^{19}$

But might not a more drastic theory serve to make a dividend credit effective? For example, what if a cumulative-if-earned theory were adopted whereby the noncumulative stock would possess the incidents of cumulative except for the unearned dividend credit? ${ }^{20}$ The position of a noncumulative shareholder with a dividend credit would then be identical to that of a cumulative shareholder with arrearages. Apart from the dicta in the Lich and Dohme cases, the cumulative-if-earned approach would differ from the New Jersey rule in that the subsequent level of earned surplus would be immaterial, thus avoiding needless and arbitrary complexities.

19 The Cast Iron Pipe cases did not face the problem head-on since the earnings there were so clearly representable in readily available securities. Of course, the creation of added surplus and the "earning of the earnings" were simultaneous. The association of the earnings with particular assets implies a nonexistent time sequence. This is not harmful in itself, but makes much easier a development such as the "ordinary business purpose" doctrine. However, the quick convertibility of the assets associated with earnings, while emphasized by the Bassett court, was not decisive there as the lower court points out by way of dictum: "[A]ny amount taken from actual working capital . . . is at once restored to the character it originally had." Bassett v. United States Cast Iron Pipe and Foundry Co., 74 N.J. Eq. 668, 70 Atl. 929 (Igo8). The Bassett case is certainly clear where the eamings are "in" securities and where dividends to common would impair the surplus representing withheld earnings. Judge Learned Hand in his dissent in the Wabash case, thought that the Bassett case was ambiguous where the working capital representing earnings is unimpaired, but distributions to common are made from other sources. Would such distribution be enjoined? Barclay v. Wabash Railway Co., 30 F. 2d 260, 267 et seq. (C.A. 2d, I929). In view of the Day case it seems this ambiguity should be resolved in favor of a strict interpretation of the credit. See text at note II supra. Note that even if distribution is allowed in the instance cited the book value of the credit remains unimpaired. It is dubious how much it is worth, however, if it remains sunk in the company while common continues to receive dividends. Under the analysis of note 5 supra, indefinite retention of the credited sum would amount to its appropriation for common. Consequently, it must be admitted that insofar as ambiguity existed the policy of the credit was endangered.

Whatever was true before the Lich case, the Lich, Agnew, and Dohme cases, all decided in the last decade, clearly distort the rule. Thus the Agnew case states that "dividends earned but withheld and retained as surplus and not utilized in the business [are subject to the dividend credit]." Agnew v. American Ice Co., 2 N.J. 29I, 303, 66 A. 2d 330, 336 (I949). These cases, of course, all followed the Wabash case. Thus either the New Jersey court has intentionally made a substantive change in its doctrine, perhaps in the light of that case, or a latent inconsistency not made clear in the early cases because of their special facts has finally been manifested. Assuming the latter to $\overline{b e}$ true, it is interesting to speculate whether the New Jersey court would have promulgated the doctrine if it had fully considered the consequences of its consistent application.

${ }^{20}$ Frey, in effect, advocates a cumulative-if-earned rule. See Frey, op. cit. supra, note 3. Berle, on the other hand, was concerned with segregating part of earned surplus in favor of the dividend credit. See Berle, op. cit. supra, note 3. Judge Manton appeared to have advocated a cumulative-if-earned theory in speaking for the circuit court in the Wabash case. Barclay $v$. Wabash Railway Co., 30 F. 2d 260 (C.A. 2d, 1929). 